\title{
Analyses of human papillomavirus genotypes and viral loads in anogenital warts.
}

\begin{tabular}{|r|l|}
\hline Journal: & Journal of Medical Virology \\
\hline Manuscript ID: & JMV-10-2180.R1 \\
\hline Wiley - Manuscript type: & Research Article \\
\hline Date Submitted by the & $14-$ Feb-2011 \\
\hline Complete List of Authors: & $\begin{array}{l}\text { Ball, Siolian; University of Cambridge, Division of Virology, } \\
\text { Department of Pathology } \\
\text { Winder, David; University of Cambridge, Division of Virology, } \\
\text { Department of Pathology } \\
\text { Vaughan, Katie; University of Cambridge, Division of Virology, } \\
\text { Department of Pathology } \\
\text { Hanna, Nashat; St Mary's Hospital, GU/HIV Medicine } \\
\text { Levy, Jonathan; Université Paris Diderot. } \\
\text { Sterling, Jane; University of Cambridge, Division of Virology, } \\
\text { Department of Pathology } \\
\text { Stanley, Margaret; University of Cambridge, Pathology } \\
\text { Goon, Peter; University of Cambridge, Division of Virology, } \\
\text { Department of Pathology }\end{array}$ \\
\hline Keywords: & \begin{tabular}{l} 
HPV, Genital warts, E6 DNA viral loads, E6 mRNA \\
\hline
\end{tabular} \\
\hline
\end{tabular}

\section{SCHOLARONE ${ }^{\text {TM }}$ \\ Manuscripts}


1

2 Analyses of human papillomavirus genotypes and viral loads in anogenital warts.

3

4 Siolian L. R. Ball ${ }^{1 \S}$, David M. Winder ${ }^{1}$, Katie Vaughan ${ }^{1}$, Nashat Hanna ${ }^{2}$, Jonathan Levy ${ }^{3}$, Jane C.

5 Sterling ${ }^{1}$, Margaret A. Stanley $^{1}$, and Peter K. C. Goon ${ }^{1}$.

6

$7{ }^{1}$ Dept of Pathology, University of Cambridge, Tennis Court Road, Cambridge CB2 1QP, United 8 Kingdom.

$9 \quad{ }^{2}$ Dept of GU/HIV Medicine, St. Mary's Hospital, Praed Street, London W2 1NY, United Kingdom.

$10{ }^{3}$ Université Paris Diderot. ERAMUS scholar 2007.

11

12 Running title: HPV genotypes and viral loads in anogenital warts

13

$14{ }^{\S}$ Corresponding author.

15 Mailing address: Division of Virology, Department of Pathology, University of Cambridge, Level

165 laboratories block, Addenbrooke's Hospital, Hills Road, Cambridge CB2 2QQ, United Kingdom.

17 Phone: +44-1223-763424. Fax: +44-1223-336926. Email: slrb2@cam.ac.uk

18 


\section{Abstract}

2 Condylomata acuminata (genital warts) are the most common sexually transmitted viral

3 diseases. These lesions are caused by infection with mucosal human papillomaviruses (HPVs).

4 However there is limited information on HPV strain distribution involved in the molecular

5 pathogenesis of these lesions. To address this, the strain prevalence and the frequency of

6 multiple HPV infections were determined in wart tissue obtained from 31 patients attending a

7 wart clinic. These lesions were bisected and subjected to parallel DNA and mRNA extractions.

8 HPV-type prevalence and incidence of multiple infections were determined by the Roche Linear

9 Array assay. qPCR compared HPV6, 1116 and 18 viral loads and RT-qPCR measured HPV 6 and

1011 E6 genomic expression levels. $71 \%$ of these samples were infected with multiple HPVs. Only

111 sample was negative for HPV6 or 11 DNA. $48 \%$ of samples were positive for a high risk

12 (oncogenic) HPV. The results show that multiple infections in tissue are frequent and the

13 subsequent analysis of HPV6 and 11 E6 DNA viral loads suggested that other HPVs could be

14 causing lesions. Further analysis of HPV6/11 E6 mRNA levels showed that there was no

15 discernable relationship between HPV6 E6 DNA viral load and relative HPV 6 or 11 E6 mRNA

16 levels thereby questioning the relevance of viral load to lesion causality.

17 Keywords: HPV. Genital warts. E6 DNA viral loads. E6 mRNA. 


\section{Introduction}

2 Infection with Human papillomaviruses (HPVs) results in a major global disease burden. In

3 particular, HPVs infecting mucosal tissue cause very significant morbidity and mortality. Those

4 HPVs fall into 2 groups; the so-called 'low risk' strains that cause warts and the 'high risk'

5 (oncogenic) strains (particularly HPV 16 and 18) that are the cause of ano-genital and oro-

6 pharangeal cancers [Winder et al., 2009; zur Hausen, 2002].

7 In the uterine cervix, multiple HPV infections are frequent [Schmitt et al., 2010]. Studies using

8 highly sensitive PCR based methods for HPV strain detection in ano-genital lesions indicate that

9 multiple types (including both high and low risk strains) can also be detected in Condylomata. In

10 such circumstances it is difficult to assign causality to a specific HPV strain, although over $90 \%$

11 of these lesions are positive for HPVs 6 and 11 DNA [Brown et al., 1999]; [Aubin et al., 2008];

12 [Chan et al., 2009] and there has been a significant decline in incident wart disease since the

13 introduction of a quadrivalent L1 VLP vaccine (Gardasil ${ }^{\mathrm{TM}}$ ) raised against HPVs 6 and 11 together

14 with the oncogenic HPVs 16 and 18 in 2007 ([Fairley et al., 2009]; [Munoz et al., 2010]).

15 Clarification of the clinical relevance of the multiple HPV strains found in a wart sample from an

16 individual patient is important for understanding which HPV strain is causal and these data will

17 be informative in any cases of vaccine failure.

18 In this study, the HPV strain prevalence, the frequency of more than 1 type in condylomata and 19 the relevance of viral DNA load to early gene expression have been determined in order to in 20 assign lesion causality to HPV 6 or 11. 


\section{$1 \quad$ Materials and methods:}

\section{Clinical specimens and sample preparation.}

3 The study was approved by the local Research Ethics Committee and all patients provided

4 written informed consent for their tissues to be used for research. A total of 31

5 immunocompetent male and female patients attending the Department of GU/HIV Medicine,

6 St Mary's Hospital, London, UK, were recruited to the study. Genital wart samples were

7 obtained under local anaesthesia and the tissue bisected and snap frozen at the time of biopsy

8 for DNA and RNA extraction.

9 DNA extraction and HPV detection.

10 DNA was extracted with DNeasy ${ }^{\mathrm{TM}}$ blood and tissue kit (Qiagen, Crawley, UK), following the

11 manufacturer's instructions. HPV types in 62.5ng of sample DNA were identified using the

12 Roche Linear Array (Roche Diagnostics Ltd, Burgess Hill, UK)[Woo et al., 2007].

13 Measurement of viral load

14 For Taqman ${ }^{\mathrm{TM}}$ qPCR, primers and probes were synthesised by Sigma Genosys, Gillingham, UK.

15 The primers and probes for human GAPDH [Coleman et al., 2008], HPV6, 11 and 18 E6/7 DNA

16 and $\beta$-globin (A) [Tucker et al., 2001] and for HPV16 E6/7 DNA, and human $\beta$-Globin (B) [de

17 Boer et al., 2007] have been previously described (Supplementary table S I). Amplification was

18 performed in $20 \mu \mathrm{L}$ using $10 \mathrm{ng}$ sample DNA and Hotstart Taq (Qiagen, Crawley, UK) with cycling

19 conditions as follows: initial Taq activation and template denaturation at $95^{\circ} \mathrm{C}$ for $15 \mathrm{~min}$,

20 followed by 45 cycles of $15 \mathrm{~s}$ at $95^{\circ} \mathrm{C}$ and $60 \mathrm{~s}$ at $60^{\circ} \mathrm{C}$, with acquisition of fluorescent signal at 60

21 seconds. Amplification was performed on a Rotor-Gene 3000 (Corbett Life Science, Qiagen,

22 Crawley, UK) and data analysed using the Rotor-Gene software, v6.1. All optimisation 
1 experiments were performed in triplicate at least 3 times. It was determined that HPV18 and

2 HPV16 could be multiplexed with the additional GAPDH internal control but all other HPV

3 amplification reactions were performed separately in parallel with control reactions. Standard

4 curves were constructed using purified placental human DNA (Sigma-Aldrich, Gillingham, UK)

5 and purified plasmids containing the HPV of interest. Serial dilutions of 1 in 5 were constructed

6 (containing $100 \mathrm{ng}$ to $6.4 \mathrm{pg}$ human DNA and $10^{5}$ to 6.4 copies of HPV per reaction). The

7 specificity of primers was determined under identical conditions with genomic HPV DNA (HPVs

$81 \mathrm{a}, 2 \mathrm{a}, 3,5,6,7,8,10,11,14,16,17,18,20,31,49,50$ or 57 ) at a concentration of $10^{6}$

9 copies/ $\mu \mathrm{L}$. No significant non-specific reactions were observed. Viral load was expressed as

10 number of virus particles/cell assuming 1ng DNA 150 cells [Leyva and Kelley, 1974]. Viral loads

$11<0.01$ copies/cell were deemed as insignificant.

12 mRNA extraction, purification and cDNA synthesis.

13 The second half of the bisected tissue sample was shredded at the time of excision and stored

14 at $-80^{\circ} \mathrm{C}$ in RNAlater ${ }^{\mathrm{TM}}$ (Qiagen, Crawley, UK). The tissue was later resuspended in $200 \mu \mathrm{L}$ Trizol ${ }^{\mathrm{TM}}$

15 (Invitrogen, Paisley, UK) in a lysing matrix D tube (MP Biomedicals, Solon OH, USA) and

16 pulverised using a Bulletblender ${ }^{\mathrm{TM}}$ machine (Next Advance, Averill Park, NY,USA). RNA was

17 precipitated with isopropranol and resuspended in $50 \mu \mathrm{L} \mathrm{H}_{2} \mathrm{O}$. After DNAse I digestion, RNA was

18 recovered by column purification using PureLink ${ }^{\mathrm{TM}}$ RNA extraction kit (Invitrogen, Paisley, UK)

19 following manufacturer's instructions and a maximum of $5 \mu \mathrm{g}$ reverse transcribed using

20 Bioscript $^{\mathrm{TM}}$ (Bioline, London, UK) after pre-incubation with random hexamer primers for $5 \mathrm{~min}$ at

$2165^{\circ} \mathrm{C}$. Reactions were performed as follows: $25^{\circ} \mathrm{C}$ for $10 \mathrm{~min}, 42^{\circ} \mathrm{C}$ for $60 \mathrm{~min}$ and $70^{\circ} \mathrm{C}$ for $15 \mathrm{~min}$.

22 No-RT controls were performed without the addition of enzyme. The resulting cDNAs were 
1 diluted 1/10 with pure water before qRT-PCR analysis. RT-qPCR for HPV 6 and 11 E6/E7 was

2 performed as per qPCR with supplementary internal control primers (Supplementary table S II).

3 To enable multiplexing of mRNA internal controls, primer-pairs and probes were examined for

4 any potential primer-dimer pairs using

5 Autodimer ${ }^{\mathrm{TM}}$ (http://www.cstl.nist.gov/div831/strbase/AutoDimerHomepage/AutoDimerProgra

6 mHomepage.htm). RT-qPCR was performed for all HPVs as a single-plex assay using primers and

7 probe as listed in Table I.

8 Measurement of viral RNA load

9 Values of HPV mRNA copy number were determined by standard curves of genomic HPVs (as

10 described for DNA viral load). Relative cellular mRNA was determined by normalising CT values

11 of TBP (TATA-Box binding protein), YWHAZ (tyrosine 3-mono-oxygenase/tryptophan 5-mono-

12 oxygenase activation protein, zeta polypeptide) and HMBS (hydroxymethylbilane synthase)

13 triplex RT-qPCR to calibrator sample (sample 9). Primers and probes sequences were first

14 reported for TBP, YHWAZ and HMBS by [Radonic et al., 2005], [Ohl et al., 2006] and [Qian et al., 15 2002] respectively.

16 Data analysis and statistics

17 The results from the Linear Array assay were compared to those obtained by qPCR. Unweighted

18 Kappa statistics were calculated by online software

19 (http://www.graphpad.com/quickcalcs/kappa1.cfm). Kappa values determined were ranked as 20 moderate, substantial or near perfect as described by Viera et al. [Viera and Garrett, 2005]. 21 


\section{Results}

2 DNA from all 31 genital wart samples was positive for $\beta$-globin and HPV using the Linear Array

3 assay. All the warts harboured at least one low-risk HPV (Table I), and, as expected, HPV 6 and

411 dominated and were present in 97\%, with HPV 6 in 28 (90\%) and HPV 11 in 10 lesions (32\%).

5 In 9 lesions (29\%), only HPV 6 was found. The frequency distribution of HPV strains in this

6 cohort of tissue is featured in figure 1.

7

822 of the warts (71\%) were multiply infected (Table II). In 7 (22\%), more than one low-risk HPV 9 was detected and in 15 (48\%) a mixture of low- and high-risk types were found. 11 (35\%) of the 10 samples contained HPV16 or 18 or both. Only one sample (sample 25) was not infected by HPV 116 or 11, but was infected by other low risk types 40, 84 and CP6108 in addition to the oncogenic 12 strains 16, 18, 33 and possibly 52. Other low and high risk strains detected are shown in Table II.

14 Viral load was assayed using 10ng of sample DNA as standardization experiments had shown 15 that the Taqman ${ }^{\mathrm{TM}}$ qPCR was unbalanced with 100ng or more DNA. A threshold level for copy 16 numbers of specific HPV E6/E7 DNA was assumed to be 10 copies/cell indicating the HPV in 17 question to have been replicated and so likely to be involved in the pathogenesis of the clinical 18 lesion [Doorbar, 2006]. In addition, the sample DNA was obtained from tissue containing both 19 epithelium and stroma, so the concentration of HPV in infected keratinocytes is likely to be 20 higher than the values obtained for the full biopsy. 
1 Of the 28 warts positive for HPV 6 in Linear Array, 18 had a copy number of HPV 6 above

2 threshold value. 5 warts, in which there was co-detection of HPV 11, had a copy number of HPV

311 exceeding 10 copies/cell (Table II). 8/31 samples (26\%) did not have viral loads above

4 threshold value of either HPV 6 or 11. In 3 of these, however, HPV 16 was detected at a level

5 above 10 copies/cell and was also positive in the Linear Array assay. In 4 of these 8 samples,

6 other low risk HPV strains, which were not tested by qPCR, had been detected in the Linear

7 Array assay and so potentially could have been causal in these lesions.

8

9 HPV 6 or 11 E6/E7 transcripts were detected and quantified in 23 samples. No tissue was 10 available for RNA extraction in 3 cases. In all samples where HPV mRNA was quantified at a 11 measurable level, the same HPV type had been found by the Linear Array assay. Only sample 8 12 had very low HPV6/11 DNA and mRNA levels, suggesting that one or more of the other low risk 13 HPVs present $(55,62$, or 84$)$ could have been causal in these lesions.

15 These data show that relatively small DNA viral loads are capable of producing high mRNA 16 levels as, for example, sample 1 had only 2 copies of HPV 6 per cell, but generated a relative 17 amount of 1163 copies of HPV 6 mRNA per reaction. The converse is also true, as the sample 18 with the largest HPV 6 DNA viral load (namely sample 15 with 870 copies/cell), did not yield the 19 largest E6/7 mRNA load. Five multiply infected samples (namely 1, 4, 8, 17 and 22) had low HPV 206 DNA viral loads (<10 copies/cell) suggesting that another HPV was responsible for the lesion. 21 However, analysis of relative mRNA levels revealed measurable HPV 6 E6 transcription in 4 
1 samples $(1,4,17$ and 22$)$ thus HPV 6 could still be causing these lesions. As HPV 6 E6 mRNA was

2 not measurable in sample 8 , other low risk HPVs present $(55,62$ or 84$)$ may have been causal.

3

43 samples $(3,22$ and 25) had copies of HPV 16 DNA viral loads above 10 copies/cell, raising the

5 possibility that these lesions could be caused by HPV 16. For sample 3, HPV 11 and 16 were

6 detected by the Linear Array assay, subsequent qPCR and RT-qPCR revealed HPV 11 E6 DNA and

7 E6 mRNA levels to be negligible whilst HPV 16 DNA was present at 177 copies/cell. These data

8 suggest HPV 16 is causing the lesion, although in the absence of HPV 16 mRNA measurement it

9 can only be speculated. In sample 22 (positive for HPV 6 and 16 DNA) HPV 6 mRNA was

10 abundant even though the HPV 6 DNA load was <10 copies/cell.

11

12 Sample 25, however was negative for HPV 6 and 11 on the Linear Array assay, but positive for 13 HPV 40, 84, CP, 16, 18, 33 and 52. The absence of measurement of the low risk HPVs 40,84 and 14 CP6108 mRNAs meant that their contribution to the pathogenesis of this lesion could not be 15 discounted and it would be incautious to conclude that HPV 16 caused this lesion.

16

17 Inter-assay concordance values were derived using Cohen's $\kappa$ algorithm (Table III) [Viera and 18 Garrett, 2005]. For all comparisons agreement was considered better than 'moderate' $(\kappa>0.41)$, 19 except between Linear Array results and relative mRNA levels for HPV 6 which was determined 20 to be 'fair'. These data suggest that the presence of HPV 6 L1 DNA as determined by the Linear 21 Array assay does not predict E6 genomic expression as measured by the RT-qPCR. 
1

2 This detailed DNA and RNA analysis of HPVs in genital warts attempted to identify not just the

3 HPV strains present in or on the lesion, but also to gather evidence of the HPV strains that could

4 be causing the lesions and producing infective virions. To our knowledge, there are no previous

5 published data for this type of analysis in condylomata acuminata. Most studies of HPV types in

6 genital warts have used surface swabs and PCR amplification with sequencing or hybridization

7 methods to identify multiple infections [Chan et al., 2009; Greer et al., 1995; Giuliano et al.,

8 2008; Sanclemente et al., 2007]. These sensitive methods can also detect HPV DNAs in the

9 anogenital region in asymptomatic individuals [Nielson et al., 2009]. The potential risk from

10 analysis of surface samples is that the HPVs detected may reflect carriage but not necessarily

11 permissive viral growth. The analysis of lesion tissue should minimize false positive results due

12 to other non-lesion associated HPVs within this body area.

13

14 It was no surprise to find HPV 6 was the most frequently detected in these lesions with HPV 11

15 as the second most prevalent type. This is in accordance with previous data for other studies

16 using the Linear Array assay in genital wart swabs [Aubin et al., 2008; Chan et al., 2009] and

17 tissue [Potocnik et al., 2007]. The finding of high risk HPVs in $35 \%$ of samples in this

18 immunocompetent group is in keeping with other reports of high risk types detected in 14-44\%

19 of non-immunosuppressed individuals [Brown et al., 1999; Potocnik et al., 2007] but below that

20 found in patient groups with a higher HIV positive prevalence where high risk HPVs may be

21 present in 47-100\% of genital warts [Brown et al., 1999; Müller et al., 2010; Schlecht et al., 22 2010]. 
2 This data from immunocompetent patients show that $71 \%$ excised wart samples contained dual

3 or multiple HPV types, agreeing with previous estimates [Brown et al., 1999; Aubin et al., 2008,

4 Chan et al., 2009]. The Linear Array assay has the advantage of simultaneously detecting the

5 presence of 37 genital HPV types [Woo et al., 2007] and is considered the most sensitive test of

6 its kind [van Ham et al., 2005; van Hamont et al., 2006]. The advantage of qPCR is the ability to

7 estimate viral load, allowing comparison of specific HPV subtypes in multiply infected samples.

8 The inter-assay agreement levels between the Linear Array assay and qPCR was good and

9 validated the use of either assay for screening.

10

11 The identification of HPV strains other than 6 or 11 causing genital warts will be important for

12 future vaccination strategies, although the reduction of anogenital warts since the introduction

13 of the quadrivalent vaccine, Gardasil ${ }^{\text {TM }}$ [Fairley et al., 2009; Munoz et al., 2010], supports

14 confirmation presented here of the role of HPV 6 or 11 in causing lesions, even in multiply

15 infected samples or when their DNA loads are low. One concern is that if lesions caused by HPV

166 and 11 are eradicated, other HPVs may become more prevalent and therefore more

17 important for identification, and subsequent confirmation of which HPV is causal. Confirmation

18 and quantitation of other HPV mRNAs would be desirable, but as yet there is no equivalent of

19 the Linear Array assay for HPV mRNA analysis and this study was limited to the primer and

20 probe sets in the laboratory. The PreTect ${ }^{\mathrm{TM}}$ HPV Proofer and Aptima ${ }^{\mathrm{TM}}$ systems are designed for

21 the detection of high-risk HPV mRNA only [Halfon et al., 2010; Molden et al., 2007; Keegan et

22 al., 2009] and so would be unsuitable for Condylomata. 
2 The choice of E6/E7 transcript in this study was based on their known roles in the viral

3 infectious cycle [Doorbar, 2006]. Studies investigating the DNA and mRNA loads of oncogenic

4 HPVs in cervical intraepithelial neoplasia (CIN) have concluded that E6 RNA load is a better

5 predictor of lesion severity [de Boer et al., 2007; Cattani et al., 2009; Ho et al., 2010] and

6 progression levels [de Boer et al., 2007], and although malignant progression was not likely in

7 these lesions, E6 RNA abundance probably reflects viral contribution to lesion pathogenesis. As

8 demonstrated in this report, DNA loads of low-risk subtypes, HPV 6 and 11, do not correlate

9 with their respective mRNA E6 transcript levels and is similar to that observed in HPV 16-

10 associated CIN [de Boer et al., 2007; Cattani et al., 2009]. Therefore, viral genome copy number

11 does not directly reflect viral activity.

12

13 HPV16 is not thought to produce Condyloma-like lesions [zur Hausen, 2002] although one

14 reported case [Chrisofos et al., 2004] based on DNA analysis alone, suggests that it may. The

15 DNA analysis shows 3 samples in which HPV 16 DNA was detected by the Linear Array assay and

16 also at a significant level by qPCR, suggesting that this oncogenic type is amplified within these

17 lesions, but this can only be confirmed by quantitation of the mRNA which was not performed 18 in this study.

20 These data provide evidence for multiple subtype infection as a common event in the natural

21 history of Condylomata acuminata, but with significant replicative activity of usually HPV 6 or

22 11. DNA viral loads alone are insufficient to truly determine which HPV is causal, and mRNA 
1 analysis is required to discount the contribution of HPV 6 and/or 11 when DNA loads are low. In

2 order to confirm these findings, a prospective study including larger numbers of patients, rather

3 than an unselected collection of warts should be performed. It is likely that analysis of HPV

4 mRNA would provide data informative for HPV vaccines and will be especially useful in the

5 event of vaccine failure.

6

7 Disclosure of Conflicts of Interest

8 This work was supported by grants from the British Skin Foundation and Cancer Research UK to

9 PKCG. PKCG and MAS act as consultants to Sanofi Pasteur-MSD, Lyon, France and are in receipt 10 of an unrestricted educational grant. MAS also acts as consultant to Merck Research 11 Laboratories, Westpoint, USA, and GSK Biologicals, Rixensart, Belgium. 
Aubin F, Prétet JL, Jacquard AC, Saunier M, Carcopino X, Jaroud F, Pradat P, Soubeyrand B, Leocmach $Y$, Mougin C, Riethmuller D. 2008. Human papillomavirus genotype distribution in external acuminata condylomata: A large French national study (EDiTH IV). Clin Infect Dis 47:610-615.

Brown DR, Schroeder JM, Bryan JT, Stoler MH, Fife KH. 1999. Detection of multiple human papillomavirus types in condylomata acuminata lesions from otherwise healthy and immunosuppressed patients. J Clin Microbiol 37:3316-3322.

Cattani P, Siddu A, D'Onghia S, Marchetti S, Santangelo R, Vellone VG, Zannoni GF, Fadda G. 2009. RNA (E6 and E7) assays versus DNA (E6 and E7) assays for risk evaluation for women infected with Human papillomavirus. J Clin Microbiol 47:2136-2141.

Chan PKS, Luk ACS, Luk TNM, Lee K-F, Cheung JLK, Ho K-M, Lo K-K. 2009. Distribution of human papillomavirus types in anogenital warts of men. J Clin Virol 44:111-114.

Chrisofos M, Skolarikos A, Lazaris A, Bogris S, Deliveliotis C. 2004. HPV 16/18-associated condyloma acuminatum of the urinary bladder: first international report and review of literature. Int J STD AIDS 15:836-838.

Coleman HM, Connor V, Cheng ZSC, Grey F, Preston CM, Efstathiou S. 2008. Histone modifications associated with herpes simplex virus type 1 genomes during quiescence and following ICPOmediated de-repression. J Gen Virol 89:68-77.

de Boer MA, Jordanova ES, Kenter GG, Peters AA, Corver WE, Trimbos JB, Fleuren GJ. 2007. High Human papillomavirus oncogene mRNA expression and not viral DNA load is associated with poor prognosis in cervical cancer patients. Clin Cancer Res 13:132-138.

Doorbar J. 2006. Molecular biology of human papillomavirus infection and cervical cancer. Clin Sci 110:525-541.

Fairley CK, Hocking JS, Gurrin LC, Chen MY, Donovan B, Bradshaw C. 2009. Rapid decline in presentations for genital warts after the implementation of a national quadrivalent human papillomavirus vaccination program for young women. Sex Transm Infect:sti.2009.037788.

Giuliano AR, Tortolero-Luna G, Ferrer E, Burchell AN, de Sanjose S, Kjaer SK, Muñoz N, Schiffman M, Bosch FX. 2008. Epidemiology of human papillomavirus infection in men, cancers other than cervical and benign conditions. Vaccine 26 (Suppl 10):K17-K28.

Greer CE, Wheeler CM, Ladner MB, Beutner K, Coyne MY, Liang H, Langenberg A, Yen TS, Ralston R. 1995. Human papillomavirus (HPV) type distribution and serological response to HPV type 6 virus-like particles in patients with genital warts. J Clin Microbiol 33:2058-2063.

Halfon P, Benmoura D, Agostini A, Khiri H, Martineau A, Penaranda G, Blanc B. 2010. Relevance of HPV mRNA detection in a population of ASCUS plus women using the NucliSENS EasyQ ${ }^{\circledR}$ HPV assay. J Clin Virol 47:177-181.

Ho CM, Lee BH, Chang SF, Chien TY, Huang SH, Yan CC, Cheng WF. 2010. Type-specific human papillomavirus oncogene messenger RNA levels correlate with the severity of cervical neoplasia. Int J Cancer 127:622-632.

Keegan H, Mc Inerney J, Pilkington L, Grønn P, Silva I, Karlsen F, Bolger N, Logan C, Furuberg L, O'Leary J, Martin C. 2009. Comparison of HPV detection technologies: Hybrid capture 2, PreTect(TM) HPV-Proofer and analysis of HPV DNA viral load in HPV16, HPV18 and HPV33 E6/E7 mRNA positive specimens. J Virol Methods 155:61-66.

Leyva A, Kelley WN. 1974. Measurement of DNA in cultured human cells. Anal Biochem 62:173-179.

Molden T, Kraus I, Skomedal H, Nordstrøm T, Karlsen F. 2007. PreTect(TM) HPV-Proofer: Real-time detection and typing of E6/E7 mRNA from carcinogenic human papillomaviruses. J Virol Methods 142:204-212.

Müller EE, Chirwa TF, Lewis DA. 2010. Human papillomavirus (HPV) infection in heterosexual South African men attending sexual health services: associations between HPV and HIV serostatus. Sex Transm Infect 86:175-180. 
Munoz N, Kjaer SK, Sigurdsson K, Iversen O-E, Hernandez-Avila M, Wheeler CM, Perez G, Brown DR, Koutsky LA, Tay EH, Garcia PJ, Ault KA, Garland SM, Leodolter S, Olsson S-E, Tang GWK, Ferris DG, Paavonen J, Steben M, Bosch FX, Dillner J, Huh WK, Joura EA, Kurman RJ, Majewski S, Myers ER, Villa LL, Taddeo FJ, Roberts C, Tadesse A, Bryan JT, Lupinacci LC, Giacoletti KED, Sings HL, James MK, Hesley TM, Barr E, Haupt RM. 2010. Impact of human papillomavirus (HPV)-6/11/16/18 vaccine on all HPV-associated genital diseases in young women. J Natl Cancer Inst 102:325-339.

Nielson CM, Harris RB, Flores R, Abrahamsen M, Papenfuss MR, Dunne EF, Markowitz LE, Giuliano AR. 2009. Multiple-type Human papillomavirus infection in male anogenital sites: Prevalence and associated factors. Cancer Epidemiol Biomarkers Prev 18:1077-1083.

OhI F, Jung M, Radonic A, Sachs M, Loening SA, Jung K. 2006. Identification and validation of suitable endogenous reference genes for gene expression studies of human bladder cancer. J Urol 175:1915 - 1920.

Potocnik M, Kocjan BJ, Seme K, Poljak M. 2007. Distribution of human papillomavirus (HPV) genotypes in gentital warts from males in Slovenia. Acta Dermatovenerol Alp Panonica Adriat 16:91-98.

Qian Z, Fernald AA, Godley LA, Larson RA, Le Beau MM. 2002. Expression profiling of CD34+ hematopoietic stem/ progenitor cells reveals distinct subtypes of therapy-related acute myeloid leukemia. Proc Natl Acad Sci USA 99:14925-14930.

Radonic A, Thulke S, Bae H-G, Muller M, Siegert W, Nitsche A. 2005. Reference gene selection for quantitative real-time PCR analysis in virus infected cells: SARS corona virus, Yellow fever virus, Human Herpesvirus-6, Camelpox virus and Cytomegalovirus infections. Virology Journal 2:7.

Sanclemente G, Herrera S, Tyring SK, Rady PL, Zuleta JJ, Correa LA, He Q, Wolff JC. 2007. Human papillomavirus (HPV) viral load and HPV type in the clinical outcome of HIV-positive patients treated with imiquimod for anogenital warts and anal intraepithelial neoplasia. J Eur Acad Dermatol 21:1054-1060.

Schlecht HP, Fugelso Dana K, Murphy Ryan K, Wagner Katiri T, Doweiko John P, Proper J, Dezube Bruce J, Panther Lori A. 2010. Frequency of occult high grade squamous intraepithelial neoplasia and invasive cancer within anal condylomata in men who have sex with men. Clin Infect Dis 51:107-110.

Schmitt M, Dondog B, Waterboer T, Pawlita M, Tommasino M, Gheit T. 2010. Abundance of Multiple High-Risk Human Papillomavirus (HPV) Infections found in cervical cells analyzed by use of an ultrasensitive HPV genotyping assay. J Clin Microbiol 48:143-149.

Tucker RA, Unger ER, Holloway BP, Swan DC. 2001. Real-time PCR-based fluorescent assay for quantitation of human papillomavirus types $6,11,16$, and 18. Mol Diagn 6:39-47.

van Ham MAPC, Bakkers JMJE, Harbers GK, Quint WGV, Massuger LFAG, Melchers WJG. 2005. Comparison of two commercial assays for detection of human papillomavirus (HPV) in cervical scrape specimens: validation of the Roche AMPLICOR HPV Test as a means to screen for HPV genotypes associated with a higher risk of cervical disorders. J Clin Microbiol 43:2662-2667.

van Hamont D, van Ham MAPC, Bakkers JMJE, Massuger LFAG, Melchers WJG. 2006. Evaluation of the SPF10-INNO LiPA human papillomavirus (HPV) genotyping test and the Roche Linear Array HPV genotyping test. J Clin Microbiol 44:3122-3129.

Viera AJ, Garrett JM. 2005. Understanding interobserver agreement:The Kappa statistic. Fam Med 37:360-363.

Winder DM, Ball SLR, Vaughan K, Hanna N, Woo YL, Fränzer J-T, Sterling JC, Stanley MA, Sudhoff H, Goon PKC. 2009. Sensitive HPV detection in oropharyngeal cancers. BMC Cancer 9:440.

Woo YL, Damay I, Stanley M, Crawford R, Sterling J. 2007. The use of HPV Linear Array Assay for multiple HPV typing on archival frozen tissue and DNA specimens. J Virol Methods 142:226230. 
1 zur Hausen H. 2002. Papillomaviruses and cancer: from basic studies to clinical application. Nat Rev 2 Cancer 2:342-350.

$\begin{array}{ll}6 \\ 7 & 4\end{array}$




\section{Figures}

2

3 Supplementary table $\mathbf{S} \mathbf{I}$

4

\begin{tabular}{|c|c|c|c|c|c|}
\hline Target & $\begin{array}{l}\text { Accession } \\
\text { Number }\end{array}$ & Forward Primer & Reverse Primer & Probe & $\begin{array}{l}\text { Optimised } \\
\text { primer } \\
\text { concentration } \\
\text { (nM) }\end{array}$ \\
\hline HPV6 & AF092932 & $\begin{array}{c}\text { GTTCATAAAGCTAAATTG } \\
\text { TACGTGGAA }\end{array}$ & $\begin{array}{l}\text { TGTGAATCTTGTCCGTC } \\
\text { CACTT }\end{array}$ & $\begin{array}{c}\text { [6FAM]- } \\
\text { ACAATATCCTTTAGGGTAAC } \\
\text { ATGTCTTCCATGCATG - } \\
\text { [TAMRA] }\end{array}$ & 75 \\
\hline HPV11 & M14119 & $\begin{array}{l}\text { GCTTCATAAAACTAAATA } \\
\text { ACCAGTGGAA }\end{array}$ & $\begin{array}{c}\text { TGCGTCTTGTTTGTCCA } \\
\text { CCTT }\end{array}$ & $\begin{array}{c}\text { [6FAM]- } \\
\text { CTATATCCTTTAGGGTAACA } \\
\text { AGTCTTCCATGCATGTTG- } \\
\text { [TAMRA] } \\
\end{array}$ & 75 \\
\hline HPV16 & K02718 & $\begin{array}{c}\text { CCGGACAGAGCCCATTAC } \\
\text { AAT }\end{array}$ & $\begin{array}{c}\text { ACGTGTGCTTTGTACG } \\
\text { CAC }\end{array}$ & $\begin{array}{c}\text { [6FAM]- } \\
\text { TGTTGCAAGTGTGACTCTAC } \\
\text { GCTTCGGT-[BHQ1] }\end{array}$ & 100 \\
\hline HPV18 & NC_001357 & $\begin{array}{c}\text { CAACCGAGCACGACAGG } \\
\text { AA }\end{array}$ & $\begin{array}{c}\text { CTCGTCGGGCTGGTAA } \\
\text { ATGTT }\end{array}$ & $\begin{array}{c}{[6 F A M]-} \\
\text { AATATTAAGTATGCATGGA } \\
\text { CCTAAGGCAACATTGCAA- } \\
\text { [BHQ1] } \\
\end{array}$ & 100 \\
\hline $\begin{array}{l}\beta \text {-globin } \\
\text { (A) }\end{array}$ & NG_000007 & $\begin{array}{c}\text { CAGGTACGGCTGTCATCA } \\
\text { CTTAGA }\end{array}$ & $\begin{array}{c}\text { CATGGTGTCTGTTTGA } \\
\text { GGTTGCTA }\end{array}$ & $\begin{array}{c}\text { [TET]- } \\
\text { GCCCTGACTTTTATGCCCAG } \\
\text { CCCTG-[BHQ1] }\end{array}$ & 500 \\
\hline $\begin{array}{c}\beta \text {-globin } \\
\text { (B) }\end{array}$ & NG_000007 & $\begin{array}{c}\text { GACAGGTACGGCTGTCA } \\
\text { TCA }\end{array}$ & $\begin{array}{c}\text { TAGATGGCTCTGCCCT } \\
\text { GACT }\end{array}$ & $\begin{array}{c}\text { [TET]- } \\
\text { CTAGGGTTGGCCAATCTAC } \\
\text { TCCCAG-[BHQ1] }\end{array}$ & 100 \\
\hline GAPDH & NM_002046 & $\begin{array}{c}\text { CGGCTACTAGCGGTTTTA } \\
\text { CG }\end{array}$ & $\begin{array}{c}\text { AAGAAGATGCGGCTG } \\
\text { ACTGT }\end{array}$ & $\begin{array}{c}\text { [Cy5]- } \\
\text { CACGTAGCTCAGGCCTCAA } \\
\text { GACCT-[BHQ3] }\end{array}$ & 300 \\
\hline
\end{tabular}

5

6

7 Supplementary table I.

\section{Primers and probe sets used in qPCR assay of viral load.}

9 Primer/probe sets used for the detection of HPV and Human DNA in DNA samples

10 generated from wart tissue. Sequences are represented $5^{\prime}-3^{\prime}$ and the $5^{\prime}$ fluorescent labels

11 indicated (6FAM - 6-carboxyfluorescin, TET - tetrachloro-6-carboxyfluorescein or Cy5 -

12 cyanine). Tetramethylrhodamine (TAMRA), Black Hole Quencher 1 (BHQ1) or Black Hole

13 Quencher 3 (BHQ3) was incorporated at the 3' end of each probe. 
2

3

\begin{tabular}{|c|c|c|c|c|c|}
\hline Target & $\begin{array}{c}\text { Accession } \\
\text { Number }\end{array}$ & Forward Primer & Reverse Primer & Probe & $\begin{array}{c}\text { [Primer] } \\
\text { (nM) }\end{array}$ \\
\hline $\begin{array}{c}\text { TBP } \\
(233)\end{array}$ & NM_003194 & $\begin{array}{c}\text { TTCGGAGAGTTC } \\
\text { TGGGATTGTA }\end{array}$ & $\begin{array}{c}\text { TGGACTGTTCTTC } \\
\text { ACTCTTGGC }\end{array}$ & $\begin{array}{c}\text { [6FAM]- } \\
\text { CCGTGTTCGTGGCTCTCTT } \\
\text { ATCCTCAT- [BHQ1] }\end{array}$ & 60 \\
\hline $\begin{array}{c}\text { YWHAZ } \\
(196)\end{array}$ & NM_145690 & $\begin{array}{c}\text { AAGTTCTTGATCC } \\
\text { CCAATGCTT }\end{array}$ & $\begin{array}{c}\text { GTCTGATAGGAT } \\
\text { GTGTTGGTTGC }\end{array}$ & $\begin{array}{c}\text { TATGCTTGTTGTGACTGATC } \\
\text { GACAATCCCT-[BHQ2] }\end{array}$ & 80 \\
\hline $\begin{array}{c}\text { HMBS } \\
(82)\end{array}$ & NM_000190 & $\begin{array}{c}\text { ACTTTCCAAGCG } \\
\text { GAGCCAT }\end{array}$ & $\begin{array}{c}\text { CGATTCACTCTC } \\
\text { ATCTTTGG }\end{array}$ & $\begin{array}{c}\text { CGGCTGCAACGGCGGAAG } \\
\text { AAAAC-[BHQ3] }\end{array}$ & 100 \\
\hline
\end{tabular}

5 Supplementary table S II.

\section{6 mRNA housekeeping/internal control primer sequences and probe sets.}

7 Primer/probe sets used for the detection of internal control housekeeping transcripts in cDNA

8 samples. Sequences are represented 5'-3' and the $5^{\prime}$ fluorescent labels indicated (6FAM - 6-

9 carboxyfluorescin, TET - tetrachloro-6-carboxyfluorescein or Cy5 - cyanine). Tetramethylrhodamine

10 (TAMRA), Black Hole Quencher 1 (BHQ1) or Black Hole Quencher 2 (BHQ2) was incorporated at the 113 ' end of each probe. Amplicon size is in brackets (number of base pairs). 
1 Table I

2 3

\begin{tabular}{|c|c|}
\hline & Number of samples (\%) \\
\hline HPV positive & $31(100)$ \\
\hline HPV6+ & $28(90)$ \\
\hline HPV6 plus other & $21(68)$ \\
\hline HPV11 + & $10(32)$ \\
\hline High Risk HPV+ & $15(48)$ \\
\hline Single Infections & $9(29)$ \\
\hline Dual infections & $11(35)$ \\
\hline Triple Infections & $3(10)$ \\
\hline More than 3 HPVs present & $8(26)$ \\
\hline
\end{tabular}

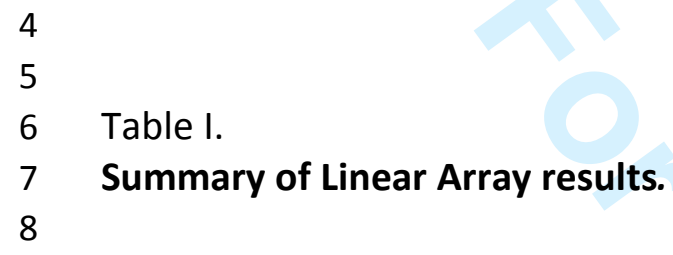


2

\begin{tabular}{llcc}
\hline & Linear Array Result & Taqman $^{\text {TM }}$ qPCR results. & $\begin{array}{c}\text { Relative HPV RNA } \\
\text { load }\end{array}$ \\
$\begin{array}{c}\text { Sample } \\
\text { Number }\end{array}$ & (HPV type present) & (copies/cell) & (copies/reaction)
\end{tabular}

\begin{tabular}{|c|c|c|c|c|c|c|c|c|}
\hline & Low risk & High risk & HPV6 & HPV11 & HPV16 & HPV18 & HPV6 & HPV11 \\
\hline 1 & 6,40 & 18 & 2 & - & - & - & 1163 & - \\
\hline 2 & 6 & & 13 & - & - & - & 354 & - \\
\hline 3 & 11 & 16 & - & - & 177 & - & - & - \\
\hline 4 & 6,42 & & 3 & - & - & - & 53 & - \\
\hline 5 & 6 & & 27 & - & - & - & NA & NA \\
\hline 6 & 6,11 & & - & 51 & - & - & - & 71 \\
\hline 7 & $6,42,54, C P$ & 31,39 & 198 & - & - & - & 18 & - \\
\hline 8 & $6,55,62,84$ & 45 & - & - & - & - & - & - \\
\hline 9 & 6,11 & & 46 & - & - & - & 4764 & - \\
\hline 10 & 6,11 & & - & 123 & - & - & - & 6905 \\
\hline 11 & 6 & 18 & 14 & - & - & - & 5630 & - \\
\hline 12 & 6 & & 351 & - & - & - & 20 & - \\
\hline 13 & $6,11, \mathrm{CP}$ & 16 & - & 190 & - & - & - & 21604 \\
\hline 14 & 6 & & 35 & - & - & - & NA & NA \\
\hline 15 & 6 & $18,45,51,59$ & 870 & - & - & - & 4036 & - \\
\hline 16 & 6 & & 59 & - & - & - & 21735 & - \\
\hline 17 & 6,67 & $52 ? 58$ & 8 & - & - & - & 243 & - \\
\hline 18 & 6 & 18 & 12 & - & - & - & 2712 & - \\
\hline 19 & 6,11 & & 456 & - & - & - & 51 & - \\
\hline 20 & $6,11,69,84$ & 16 & - & 251 & - & - & 6 & 67 \\
\hline 21 & 6 & & 26 & - & - & - & 493 & - \\
\hline 22 & 6 & 16 & 3 & - & 16 & - & 141 & - \\
\hline 23 & 6 & & 147 & - & - & - & 616 & - \\
\hline 24 & 6 & & 12 & - & - & - & 959 & - \\
\hline 25 & $40,84, C P$ & $16,18,33,52 ?$ & - & - & 11 & - & - & - \\
\hline 26 & 6,11 & & 85 & - & - & - & 3715 & 13 \\
\hline 27 & 6 & 45 & 203 & - & - & - & - & - \\
\hline 28 & 6 & 18,59 & 61 & - & - & - & 3289 & - \\
\hline 29 & $6,11,84$ & & 19 & 558 & - & - & 676 & 7662 \\
\hline 30 & $11,42,64$ & 18 & - & 284 & - & - & NA & NA \\
\hline 31 & 6 & & - & - & - & - & - & - \\
\hline
\end{tabular}

3

4 Table II.

5 Linear Array Results vs qPCR Viral Load and Relative RNA load.

6 Samples were assayed for the appearance and DNA and RNA viral load of HPV as described in the methods

7 section. (-) denotes not significantly positive during assay (less than 1 copy/cell or 5 copies/reaction total RNA).

8 CP represents CP6108. 52? denotes positivity at the 52/33/35/58 band on the Linear Array, but also for 9 individual 33 and 58 markers, but where the presence of 52 cannot be discounted as described in the 10 manufacturer's instructions. NA denotes no tissue available for RNA analysis. 
1 Table III.

2 3

\begin{tabular}{|c|c|c|}
\hline Comparison between positive results & HPV6 & HPV11 \\
\hline Linear Array vs qPCR DNA & 0.415 & 0.67 \\
\hline Linear Array vs RT-qPCR RNA & 0.323 & 0.731 \\
\hline qPCR DNA vs RT-qPCR RNA & 0.825 & 0.887 \\
\hline
\end{tabular}

\section{4}

5

6 Table III.

\section{Interassay concordance data.}

8 Cohen's $\kappa$ coefficients were derived as described in the methods section. 
1 Figure 1

2

3

4

5

6 Fig. 1.

7 Distribution of HPV types in wart tissue as determined by Linear Array.

8 All occurrences of HPV were scored, regardless of being single or multiple infections.

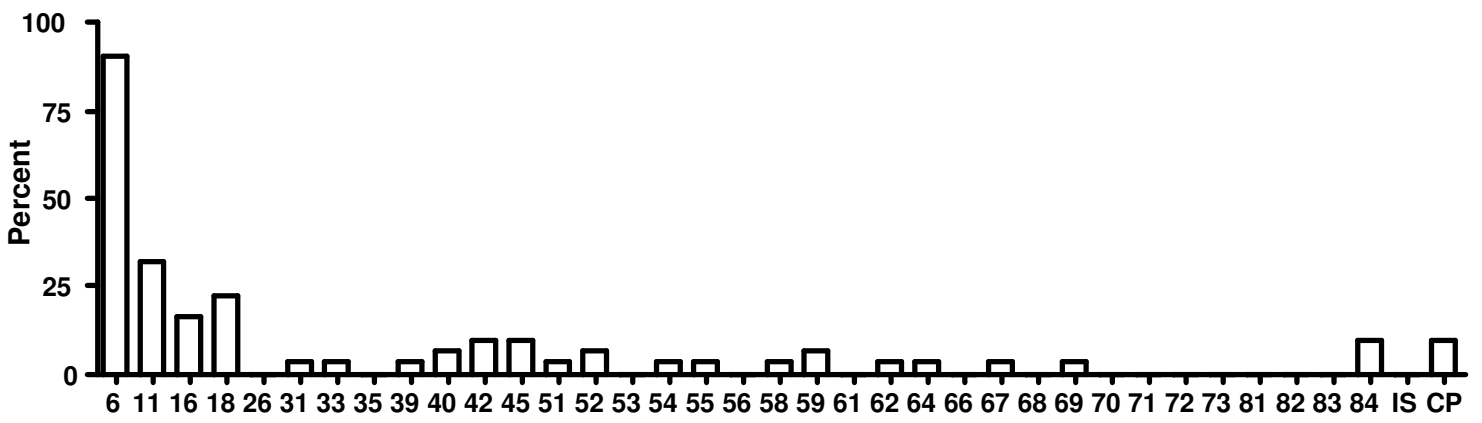
HPV

9
10
11

